\title{
EL ESPÍRITU DE LA CONTRARREFORMA. SOR HIPÓlitA DE JESÚS A TRAVÉS DE SUS CARTAS
}

\section{THE SPIRIT OF THE COUNTER-REFORMATION. SOR HIPÓLITA DE JESÚS THROUGH HER LETTERS}

AitANA FinESTRAT MARTÍNEZ

Universidad Autónoma de Barcelona

https://orcid.org/0000-0001-9797-2620

RESUMEN: El 12 de julio de 1564 Felipe II decreta oficialmente el cumplimiento de lo acordado en el Concilio de Trento. Comenzaría entonces la instauración de las medidas de la llamada «Contrarreforma» católica en España, poniéndose en marcha una serie de resortes que conducirán a España hacia una vivencia más exagerada y externalizada de la religión. Con reformas que afectan directamente a la sociedad, no se puede negar la gran influencia en sus mentalidades y en su vida cotidiana. Isabel de Rocabertí, como parte de esa sociedad y producto de esta, se vería directamente influida por su contexto.

Palabras clave: Contrarreforma, Hipólita, cartas, convento, espiritualidad

Abstract: On July 12, 1564, Philip II of Spain officially decreed the compliance with all the agreements met in the Council of Trent. In that moment began the establishment of the measures of the so-called 
Catholic "Counter-Reformation" in Spain starting up a series of events that will lead Spain and its people to a more exaggerated and excessive religious experience. With reforms that directly affect the society, the great influence on their mentalities and daily life cannot be denied. Isabel de Rocabertí, as part of that society and a product of the same, was surely influenced by her context.

Key words: Counter-Reformation, Hipólita, letters, convent, spirituality

Como es bien sabido, el siglo XVI en Europa es un momento de grandes cambios religiosos, políticos y sociales, causa y consecuencia de profundas inquietudes que hacen mella en la población. El largo y complejo proceso conocido como Contrarreforma forma parte de estas transformaciones, e influye en las mismas. No cabe duda de que reflexionar sobre la recepción y reflexión de la sociedad ante estas imposiciones, puede aportar una interesante perspectiva de los hechos estudiados. En este estudio, la perspectiva que hemos querido destacar proviene de una sección de la población que sufriría de primera mano la nueva normativa y las zozobras propias del momento: la población femenina en los conventos. Sin embargo, no es objeto del presente estudio resumir las generalidades, sino atender al caso particular desde una perspectiva casi microhistórica. Para poder aportar una visión interna y de primera mano de las posibles consecuencias a nivel particular, hemos recuperado el testimonio de la dominica catalana Hipólita de Rocabertí, cuya vida es el perfecto modelo de lo que una religiosa de la Contrarreforma debería ser, pero cuya voz propia transmite una personalidad más compleja, que puede llegar a reflejar de manera legítima su auténtica realidad.

\section{RELIGIÓN Y RELIGIOSIDAD EN LA ÉPOCA DE TRENTO}

La relevancia de la experiencia religiosa es innegable en un siglo, el XVI, en el que están sucediendo cambios tales como una marcada evolución del pensamiento: es el siglo del erasmismo, de la predominancia de la teología en las universidades, del humanismo cristiano, siglo de expansión del luteranismo, de la ruptura de la Iglesia, entre otros. El comienzo de la Edad Moderna fue un tiempo convulso en lo que a pensamiento, y especialmente pensamiento religioso, se refiere. De hecho, la época comenzó dominada por las inquietudes religiosas y el luteranismo, que llegó a conectar con el espíritu del momento ya que promovía, entre otras cosas, el individualismo, muy presente en este tiempo en la religión, en la filosofía y el pensamiento. Sin 
embargo, la expansión de las ideas luteranas acabó provocando una ruptura de la Iglesia cristiana y, en consecuencia, el surgimiento de medidas para intentar subsanarla por parte de instituciones tanto civiles como religiosas. Estos movimientos se engloban generalmente con el término de Contrarreforma.

Lo cierto es que las necesidades de renovación en la Iglesia habían demostrado ya entonces ser una tendencia constante, casi cíclica, que, a pesar de todo, nunca se alcanzaría, precisamente por la falta de adaptación de las instituciones a una sociedad que evoluciona más rápido que las normas que la intenta controlar. Las reformas iniciadas en el Renacimiento son renovadoras y con consecuencias importantes, pero la tendencia se había iniciado tiempo atrás ${ }^{1}$ y continuará tiempo después. Poco a poco se había empezado a poner en duda la capacidad mediadora de la Iglesia y, en consecuencia, su utilidad. En definitiva, en el siglo Xvi predomina una sociedad preocupada por los problemas, consciente de la necesidad de cambio, para la que los simples sermones pronunciados desde el púlpito ya no eran suficientes. A la Iglesia de Roma le urgía reformarse. Y esto es lo que intentará a través de las medidas que se adoptarán en el conocido Concilio de Trento (1545-1563), dando paso así a una espiritualidad o moral cristiana más severa que impondrá un control social mucho mayor. Comienza con ello la llamada Contrarreforma católica, que no logrará imponerse de manera uniforme y homogénea, pues las numerosas grietas ${ }^{2}$ que presentará en su proceso de implantación se irán haciendo evidentes.

El Concilio de Trento fue un concilio ecuménico convocado por el papa Paulo III que se llevaría a cabo en diferentes sesiones entre los años 1545 y 1563, con el que se pretendía reaccionar a los movimientos de Reforma pro-

1. Ya en la Edad Media existieron problemas en la Iglesia católica. Entre otras cosas, sucederán a menudo luchas de poder entre el emperador del Sacro Imperio Romano Germánico y el papa de Roma, la Querella de las investiduras (s. XI-XII) es un buen ejemplo de ello. Las órdenes monásticas por su parte también habían comenzado a sentir la necesidad de reformas, ya desde comienzos del siglo IX, con un primer intento de renovación del monacato benedictino dentro del Imperio carolingio. Pero también la religiosidad popular y, en general, la doctrina cristiana sufriría grandes cambios en el siglo XIII con la aparición de las órdenes mendicantes, considerándose este ya un intento serio de reforma y de generar una nueva espiritualidad más interiorista y cercana a Cristo. Los primeros en asumir esta novedosa reforma serán los franciscanos, y poco a poco también los dominicos, agustinos, carmelitas etc. Por lo tanto, en el siglo XIII se habría dado ya una primera gran reforma del cristianismo católico.

2. Los problemas de imposición de algunas de las normas surgidas en Trento serán evidentes en la población, pero especialmente en el ámbito de los conventos femeninos, a los que se les impondrá una férrea clausura que no será bien recibida en muchas ocasiones. Este tema ha sido ampliamente tratado por la historiadora Ángela Atienza, en trabajos como: Ángela Atienza López: «Las grietas de la clausura tridentina. Polémicas y limitaciones de las políticas de encerramiento de las monjas...Todavía con Felipe IV» en Hispania, vol. Lxxıv, n²48, 2014, pp. 807-834; Ángela Atienza López: «Los límites de la obediencia en el mundo conventual femenino de la Edad Moderna: polémicas de clausura en la corona de Aragón, siglo XVII», en Studia Historica. Historia Moderna, vol. 40, nº 1, 2018, pp. 125-157 y Ángela Atienza López: «De reacciones, de tolerancias, de resistencias y de polémicas. Las «grietas» de la Contrarreforma y los límites del disciplinamiento social», en Hispania, vol. 74, n²48, 2014, pp. 651-660. 
testante, pero que también serviría para fijar y establecer el dogma cristiano y las medidas a tomar desde ese momento, frente a un clero degradado y una Iglesia débil. En España, Felipe II, ante la amenaza del movimiento originado años atrás por Lutero y en defensa de la ortodoxia católica, se apresurará a establecer estos mandatos en su reino, y el 12 de julio de 1564 ordena la ejecución de todo lo acordado. ${ }^{3}$ Cabe destacar, sin embargo, que este Concilio no sería sino el marco normativo general, que se irá reajustando y regulando en los años posteriores a través de numerosas bulas y breves papales, que irán introduciendo cambios hacia una religiosidad más barroca.

Según la doctora Pi Corrales, ${ }^{4}$ Trento representa la oposición a las ideas reformistas, tanto en el plano teológico como en el sociológico. Teológico porque, entre otras cosas, defenderá y reforzará el papel mediador de la Iglesia entre los hombres y Dios; y sociológico porque procurará estar presente en la vida de los fieles continuamente, ya sea a través del púlpito, los confesores, la literatura o las imágenes.

Lo que propuso el Concilio, en esencia, es un mayor rigor de las normas, generando una religiosidad exaltada de carácter contemplativo, incitando de esta manera a la oración mental y a la mortificación. En este sistema cada vez más endurecido destaca el misticismo, ${ }^{5}$ que acabaría siendo refugio para muchas mujeres. ${ }^{6}$ Santa Teresa de Jesús es precisamente uno de los mayores exponentes del misticismo español del siglo XVI, modelo y ejemplo a seguir para muchas religiosas. Estas quisieron imitar su espíritu y ánimo religioso, pero también su afán reformador y divulgador, creando conventos y escribiendo diarios y autobiografías tal y como ella hizo. Las monjas, recluidas desde Trento en una clausura férrea, empiezan por tanto a dejar por escrito sus reflexiones religiosas. Sin embargo, el Concilio también había establecido medidas $^{7}$ que tenían que ver con la educación de estas mujeres, como por

3. Curiosamente, algo que caracteriza este concilio será «la ambigüedad, no solo política sino teológica, que impregnó las conclusiones de las distintas sesiones de Trento». (RICARDo GARCÍA CÁRCEL, 1998, p. 51). Por lo tanto, la interpretación de las medidas y su puesta en funcionamiento no siempre se realizaría con la eficacia deseada.

4. Magdalena de Pazzis Pi Corrales: «Existencia de una monja: vivir el convento, sentir la Reforma (siglos XVI-XVII)», en Tiempos Modernos: Revista Electrónica de Historia Moderna, vol. 7, $\mathrm{n}^{\circ}$ 20, 2010.

5. En la tradición mística europea, destacan mujeres que escriben desde el convento como podrían ser Hildegarda de Bingen, Ángela de Fulgino o Caterina de Siena.

6 Maria Àngels Herrero Herrero: «Per manament del confessor: l'esclat de l'autobiografia femenina en l'Edat Moderna. El cas del Dietari espiritual de la il.licitana sor Gertrudis de la Santíssima Trinitat», en Ítaca. Revista de Filología nº 1, Universidad de Alicante, Alicante, 2010, p. 180.

7. Concretamente en la sesión Xxv del Concilio, que tuvo lugar entre el 3 y 4 de diciembre de 1563 se trataría el asunto de los religiosos y religiosas. Entre otras medidas, se les prohíbe terminantemente tener ninguna propiedad. Todo bien que estos hombres y mujeres poseyeran pasaría a ser propiedad del convento, de la comunidad, una vez entraran en la misma. Se establece también que no se pueda obligar a nadie a profesar (si bien las obligaciones familiares y la educación de las mujeres en el cumplimiento de estas harán que esta norma no sea totalmente cumplida) y la edad mínima para profesar se establece en 16 años, aunque esto variará según las diferentes órdenes (algunas como las carmelitas descalzas lo retrasan hasta los 17). 
ejemplo la prohibición de la lectura en lengua vulgar o la libre interpretación de la Biblia. Para poder tener acceso a estos conocimientos, las monjas se tuvieron que valer de literatura subsidiaria como libros espirituales, compendios, manuales, comentarios, sermonarios, legendarios e imágenes. ${ }^{8}$

No obstante, una de las medidas más importantes (con mayores consecuencias) tomadas en la sesión xxv del Concilio fue, como se ha mencionado, el establecimiento de la clausura de todos los conventos femeninos. ${ }^{9}$ Las mujeres no podrían salir del convento en ningún caso una vez profesas, ni tampoco se permitía a nadie entrar en ellos so pena de excomunión. Esto no fue siempre acogido de buen grado. Los motivos de esta medida serán variados, pero entre ellos, sabemos que el espíritu tridentino y una nueva idea de santidad verán la virginidad como el estado de perfección para las mujeres, y la existencia más próxima a la santidad será la de la clausura y el rigor del encierro en la vida religiosa.

De gran relevancia también es el establecimiento del sistema de la confesión. Las religiosas deberían confesarse por lo menos una vez al mes con su confesor regular (ordinario) y dos o tres veces al año con un confesor extraordinario. La confesión se ha llegado a considerar por autores como Richard van Dülmen ${ }^{10}$ como uno de los instrumentos de la constitución de la conciencia moderna, del surgimiento de ese individualismo. También $\mathrm{M}^{\mathrm{a}}$ Ángeles Herrero ${ }^{11}$ establece el paso por los confesionarios y esta reflexión previa sobre el «yo mismo» como aquello que precedería a la redacción definitiva de la autobiografía, género que comenzó a cultivarse con más fuerza a partir de entonces. La figura del confesor, además, sería clave para el establecimiento de los pensamientos de la Contrarreforma. Este no solo sería un instrumento fundamental para imponer la represión, sino que también fue muchas veces culpable del aumento de textos autobiográficos, escritos por mujeres y hombres de las diferentes órdenes conventuales bajo su mandato (siendo mucho más abundantes, eso sí, las de las órdenes femeninas). Se escribirán autobiografías, ideas de perfección o virtudes, memoriales de carácter espiritual en los que se intentan mostrar como defensoras de la ortodoxia católica frente a los luteranos, alumbrados etc. ${ }^{12}$ El confesor es, además, el

8. Adriana VAlerio: «La Biblia, las mujeres y la crisis de la Europa Moderna», en Maria LaURA Giordano y Adriana Valerio (eds.): Reformas y Contrarreformas de la Europa Católica (siglos XVXVII), Verbo Divino, Navarra, 2016, p. 35.

9. La bula Circa Pastoralis promulgada en 1566 por Pío V regulará con más precisión la rigurosa clausura de las religiosas que ya se había tratado en Trento. Con esta bula se impondría la clausura total y efectiva tanto a monjas como a terciarias y a arrepentidas.

10. Richard Van Dülmen: El descubrimiento del individuo 1500-1800, Siglo xxi España, Madrid 2016.

11. Maria Àngels Herrero Herrero: «Per manament del confessor: l'esclat de l'autobiografia femenina en l'Edat Moderna. El cas del Dietari espiritual de la il-licitana sor Gertrudis de la Santíssima Trinitat», en Ítaca. Revista de Filología n¹, Universidad de Alicante, Alicante, 2010, pp. 179-190.

12. Pazzis Pi Corrales: «Existencia de una [...],» p. 34. 
contacto de las religiosas con el mundo exterior y jugó un papel fundamental en la transmisión de noticias del mundo exterior al interior de los conventos. Sin embargo, investigadores como la doctora Pi Corrales ${ }^{13}$ han expresado serias dudas sobre la posibilidad de que, por ejemplo, aspectos tan importantes de este siglo como la Reforma y los nuevos preceptos del humanismo religioso llegaran a penetrar en los conventos y afectar a sus moradoras.

Precisamente para poder conocer hasta qué punto las religiosas entienden y conocen su entorno y en qué medida les afecta, es fundamental recurrir a los egodocumentos. ${ }^{14}$ En este caso, se ha considerado la correspondencia personal como fuente principal para conocer la verdadera voz de estas mujeres. Desde la correspondencia con sus confesores hasta la correspondencia más personal dirigida a conocidos y familiares, estas cartas ofrecen una pequeña visión de su verdadero mundo interior. En este sentido, cabe destacar que los conventos se han considerado por la historiografía como lugares privilegiados para el desarrollo de la escritura femenina, lo cual se ve reflejado, por ejemplo, en esa intensa actividad epistolar llevada a cabo. Sin embargo, el rígido y restrictivo espíritu contrarreformista, consideraba que la mujer no debía ni necesitaba saber leer ni escribir. ${ }^{15}$ No obstante, es en estos momentos cuando la educación empieza a cobrar importancia (se crean escuelas y universidades por todo el territorio), y la mujer religiosa, dedicada a una vida de estudio e introspección, también aprenderá a escribir. ${ }^{16} \mathrm{Y}$ así lo hará, ya fueran memorias, diarios espirituales, relatos de favores, autobiografías ${ }^{17} \mathrm{o}$, muy a menudo, cartas.

13. Ibidem, p. 10.

14. Los egodocumentos, término utilizado por primera vez por el historiador Jacques Presser, son aquellos escritos sobre la experiencia personal, pensamientos o sentimientos, redactados generalmente en primera persona, que suelen incluir una amplia variedad de documentos, entre ellos: correspondencia, autobiografías, diarios, relatos de viajes etc.

15. Por ejemplo el jesuita Gaspar de Astete comentaría en su Tratado del gobierno de la familia y estado de las viudas y doncellas (1597) que «a las mujeres no les era absolutamente necesario aprender a escribir y contar puesto que su "gloria" estaba en el huso, la rueca y la almohadilla, pero nunca en la pluma o en la espada, atributos del varón» (visto en: Antonio Gómez Castillo y Verónica Sierra Blas (dirs.), Cinco siglos de cartas: historia y prácticas epistolares en las épocas moderna y contemporánea, Universidad de Huelva, Huelva, 2014, pág.144).

16 Según apuntaban Nieves Baranda y M. ${ }^{a}$ Carmen Marín: «En su conjunto las monjas son el colectivo más educado entre las mujeres, ya que saben leer y escribir en un porcentaje muy superior a la media». Visto en: Nieves Baranda Leturio y M. ${ }^{a}$ CARMen Marín Pina: «El universo de la escritura conventual femenina: deslindes y perspectivas», en Letras en la celda: cultura escrita de los conventos femeninos en la España moderna, Tiempo emulado, Historia de América y España, 32, 2014, p. 12.

17. El estudio de referencia sobre autobiografías femeninas de religiosas en lo que se refiere a la Edad Moderna española, es sin lugar a duda la obra de Isabelle Poutrin: Le Voile et la plume: autobiographie et sainteté féminine dans l'Espagne moderne, de consulta obligatoria para todos los estudios sobre este tipo de egodocumentos espirituales femeninos, textos escritos por mandato de los confesores, que no siempre encajan con las particularidades del género literario de la autobiografía. Mediante estos egodocumentos. Poutrin afirma que las autoras, a pesar de las numerosas injerencias externas, podrían haber llegado a expresar su subjetividad y sus propias experiencias individuales. Visto en IsAbelle Poutrin: "Autobiografías», en Nieves Baranda Leturio y Anne J. Cruz (ed.): Las escritoras españolas de la Edad Moderna. Historia y guía para la investigación, UNED, 2018. 
Antonio Castillo expresa que «las cartas eran el fruto de la negociación establecida entre la libertad de escribir, los temores a hacerlo cuando quien escribe es una mujer, la autocensura respecto de ciertos asuntos, las restricciones impuestas por determinados corresponsales y, por supuesto, la vigilancia ejercida por los superiores.» ${ }^{18}$ Por ello, aunque la correspondencia conservada a día de hoy puede transmitir mucha información, hay que tener en cuenta que las religiosas tuvieron presente esa peligrosa censura que les impide escribir con total libertad. Las cartas son por tanto fuentes que estudiar con mucha precaución, teniendo en cuenta las posibles influencias externas y verdaderas intenciones, pero al tener tintes personales, deberían ser capaces de reflejar en cierta medida sus opiniones y pensamientos.

\section{El espíritu de Trento reflejado en las Cartas de Hipólita DE JESÚS}

Es en este contexto en el que surge la figura de Hipólita de Jesús, llamada en el siglo doña Isabel de Rocabertí. De noble linaje, Isabel era hija ilegítima de Don Francisco Dalmau, vizconde de Rocabertí. Según fray Antonio de Lorea, ${ }^{19}$ autor de su biografía póstuma, Isabel «era de la Casa de Rocabertí, de los Señores por la gracia de Dios Vizcondes de Rocabertí, nació con obligaciones de ser Santa pues tenía en sus venas la sangre más roja y la nobleza más antigua que ha venerado Europa en el discurso de casi mil años $(\ldots){ }^{20}$ Nacida un 22 de enero de $1551^{21}$ en Barcelona, Isabel entrará, al parecer por su propia voluntad, ${ }^{22}$ en el monasterio de Nuestra Señora de los Ángeles de Barcelona, de la orden de Santo Domingo, a los 11 años. Era priora de este monasterio su tía, sor Jerónima de Rocabertí.

Según Lorea, Isabel hasta los 11 años había tenido vocación de santa, dedicada siempre a la oración y al aprendizaje de la religión. Sin embargo, al entrar en el convento esto cambia y la niña perderá el interés por la dedicación a la religión, se le «resfrían los deseos de santa». ${ }^{23}$ Esto la atormentará

18. Antonio Gómez Castillo y Verónica Sierra Blas (dirs.): Cinco siglos de cartas: historia y prácticas epistolares en las épocas moderna y contemporánea, Universidad de Huelva, Huelva, 2014, p. 149.

19. Antonio de Lorea: La venerable madre Hipólita de Jesús y Rocabertí, religiosa de la orden de n.p.s. Domingo en el monasterio de nuestra Señora de los Ángeles de la ciudad de Barcelona. Epitome de su prodigiosa vida, virtudes y admirables escritos, sacados de los procesos de su beatificación, y canonización, y otros instrumentos auténticos, Vicente Cabrera, Valencia, 1679.

20. Ibidem, p. 3.

21. Existen diferentes fechas posibles para su nacimiento. Según escribió Antonio de Lorea en una fe de erratas de su biografía, nace en 1551 y «tomó el hábito» a los once años cumplidos en 1562. En la primera versión explicaba que nació en 1549 y entró en el monasterio el 30 de septiembre del 1564.

22. Según su biografía escrita por fray Antonio de Lorea cronista dominico en 1679.

23. LOREA: La venerable madre [...], p. 7. 
toda la vida, a pesar de que según fray Antonio de Lorea, era algo habitual, que le había sucedido incluso a la propia Santa Teresa. ${ }^{24}$ Finalmente, a los 16 años profesa como monja dominica con el nombre de sor Hipólita de Jesús y es entonces cuando vuelve a esa actitud de dedicación santa a la religión. Es tanta y tan alta su vocación que comenzará a infligirse tormentos y sacrificios a modo de penitencia de manera muy constante y violenta. Esto le provocará una «calentura continua por más de cuarenta años». ${ }^{25}$ Para el resto de su vida sufrirá de una débil salud con esa calentura y dolores de estómago. Esta dedicación y exageración con los tormentos la podemos ver reflejada en su correspondencia, de donde podemos deducir que hasta su propio confesor le impide o prohíbe realizarlos, pues ponía en riesgo su vida. Incluso esta misma exageración en sus expresiones de humildad y servidumbre a la religión, le provocarían problemas con sus propias hermanas. Por ejemplo, se explica que su hábito estaba tan roto y gastado que sus hermanas la reprendían y se quejaban, en palabras de Antonio de Lorea: «Afrentábanse las religiosas de verla tan pobre, y avergonzadas de que les parecía las afrentaba con aquellos remiendos, y pobreza que ellas llamaban indecencia». ${ }^{26}{ }^{27}$ Hipólita es tan dura y sufrida que no deseaba estar en el locutorio ni hablar con la gente de asuntos prosaicos, ni siquiera recibir visitas de familiares. Además, se juzga a sí misma tan pecadora e indigna de llevar el hábito que le provoca calentura. Esto, según Lorea, no lo ha visto ni en Santa Teresa ni en Santa Rosa (ambas también reconocidas por su humildad). ${ }^{28}$

La priora la designará maestra de novicias, misión que cumplirá, pero siempre rechazará los ofrecimientos de ser priora a causa de su extrema humildad. Sin embargo, a lo largo de su vida escribió diversas obras demostrando un conocimiento y una sabiduría sorprendentes. Su amplia producción escrita se recogerá en 24 volúmenes, donde se pueden leer biografías de otras monjas, su propia autobiografía (escrita siguiendo la orden de su confesor, el maestro fray Raimundo Sansón), poemas, tratados espirituales, etc. Antonio de Lorea atestigua el mérito de una mujer no instruida que conoce los escritos de los Santos Padres, los entiende, y los puede enseñar a través de sus obras. Apuntes que demuestran que ha sido agraciada por Dios, pues-

24. Las comparaciones de sor Hipólita con Santa Teresa son constantes. Se ve clara la intención de hacer una comparación que las equipare para conseguir esa sensación de santidad en la figura de sor Hipólita.

25. Lorea: La venerable madre [...], Prólogo.

26. Ibidem, p. 21.

27. Estas afirmaciones sirven también para reflejar el comportamiento general de las religiosas en estos momentos. Aunque la intención es resaltar la santidad de Hipólita, la realidad es que nos está transmitiendo una forma de vida en el interior de los conventos muy alejado del ideal de religiosa. Las monjas, muchas ellas de linaje noble, siguen preocupándose por aspectos mundanos y no desean ver ni sufrir ese tipo de actitudes extremas de exaltación.

28. «ni de ninguno otro Santo me acuerdo haberlo visto escrito», visto en: LOREA: La venerable madre $[\ldots]$, p. 27 
to que le está transmitiendo un conocimiento que ella supuestamente no debería tener ni entender por su doble condición de mujer y monja, alejada (en teoría) de los sistemas de educación establecidos. Sor Hipólita escribía entonces por inspiración divina. ${ }^{29}$

Hipólita morirá finalmente un 6 de agosto de 1624, a la edad de 73 años. Tras su muerte y gracias a su sobrino, Juan Tomás de Rocabertí, arzobispo de Valencia, se iniciará un proceso de beatificación. Este sería precisamente quien encargaría ${ }^{30}$ la redacción de su biografía escrita por fray Antonio de Lorea. ${ }^{31}$ Sin embargo, este proceso no llegará a buen término y, de hecho, las obras de Hipólita serán incluidas en el Índice de libros prohibidos de la Inquisición en 1687, un momento en que la amenaza del quietismo o molinosismo estaba en pleno auge. ${ }^{32}$

A priori y solo leyendo su biografía, Hipólita sería el ejemplo perfecto de producto de la Contrarreforma. Una mujer que nace en una familia noble, se introduce en un convento de clausura siendo niña y, con un gran sentido de la humildad, la santidad y la vocación, consagra su vida a la religión hasta el final de sus días. Su vida es uno de esos ideales de mujeres con aire de santas que enorgullecían a la Iglesia con sus sacrificios y mortificaciones. Además, ha sido tocada por la gracia de Dios, pues conoce sus palabras y es capaz de transmitirlas por escrito. Sin embargo, esto podría ser poco más que un relato ideal de un «modelo de religiosa», conveniente para la buena publicidad de la Iglesia del momento. ${ }^{33}$ Es por ello que sus cartas se convierten en pieza clave para tratar de entender su verdadera personalidad.

29. «[...] una mujer sin haber aprendido más que leer , y escribir , tener inteligencia perfectísima de la lengua latina, acomodar a su propósito muchas cláusulas con grande Magisterio en la Gramática, una profundísima inteligencia de la Sagrada Escritura, y de sus misterios, y dificultades, en que suelen trabajar los grandes ingenios, un Magisterio admirable de los Dogmas, y principios de nuestra Santa Fe Católica, una comprensión grande de los escritos de los Santos Padres, y Concilios, pues lo sublimado de San Dionisio, lo recóndito de las Epístolas de San Pablo, lo profundo de San Agustín, lo elocuente de San Juan Crisóstomo, lo agudo de San Cipriano, lo dulce de San Bernardo, lo retórico de San León Papa, (...) que recomendación no deben tener consigo los escritos de esta Venerable Madre, a quien los Santos Doctores la enseñaban, la instruían y la ilustraban». LoreA: La venerable madre [...], en Prólogo y Protestación del Autor.

30. En el fondo, tras estas intenciones subyacía la intención de conseguir recuperar el prestigio de la familia Rocabertí, dañado durante la revuelta catalana de 1640 (la Guerra dels Segadors).

31. Sin embargo, esta no fue la primera biografía escrita sobre Hipólita. Al parecer cuando Lorea se dispuso a escribir su obra, existían ya otras dos previas: una escrita por un dominico anónimo en 1672 y otra escrita por Juan de Ribas con el título Vida de la venerable Hipólita de Rocabertí, desaparecida hoy en día. Visto en: LAiA De Ahumada Batlle: «Hipólita de Jesús. Biografía y bibliografía», en Rosa María Alabrús (ed.): La vida cotidiana y la sociabilidad de los dominicos: entre el convento y las misiones (siglos XVI, XVII Y XVIII), Arpegio, San Cugat, 2013, p. 137.

32. Rosa María Alabrús Iglesias: «Los confesores y los relatos autobiográficos de monjas en la transición del siglo XVI al siglo xviI: Hipólita de Rocabertí y Ana Domenge», en Pedralbes: Revista d'història moderna, n 37, 2017, p. 108.

33. Hipólita vivió durante la segunda mitad del siglo xvI, momento en que las reformas ya estaban instauradas y asentadas, lo que la separa en el tiempo y el contexto de personajes como Santa Teresa de Jesús, que viven los primeros intentos ilusionantes de reforma católica. 
La carta, en general, se escribe con una misión o funcionalidad práctica básica, que es la de la transmisión de información entre un emisor y un receptor que se encuentran separados por una distancia física. Sin embargo, en esta transmisión de información, también se transmiten ideas y, si se trata de cartas privadas, estarán expresando muy probablemente los propios pensamientos, creencias y preocupaciones del emisor. Desgraciadamente, es difícil que se conserven los epistolarios conventuales. Al fin y al cabo, la carta tiene un carácter funcional efímero. Una vez se ha transmitido el mensaje, carece de utilidad. Además, hay que contar siempre con la censura (y autocensura) con la que escriben las monjas, cuyas cartas son revisadas siempre por las prioras y abadesas antes de salir del convento. ${ }^{34} \mathrm{~A}$ pesar de todo, es necesario destacar el papel de las cartas para estudiar aspectos cotidianos y de la vida de estas mujeres pese a la censura, teniendo en cuenta lo que no dicen e interpretando bien lo que dicen, pues mucho se puede interpretar a través del texto. Por ello las cartas de Hipólita nos pueden aportar una valiosa información sobre su vida.

Actualmente se pueden leer 8 cartas completas y 7 fragmentos en la biografía escrita por fray Antonio de Lorea. Además, en el archivo del convento de los Ángeles, la historiadora Laia de Ahumada encontraría tres cartas más, publicadas en su artículo del 2011: «La carta privada a l'època moderna: un epistolari conventual femení inèdit». ${ }^{35}$ Por tanto, actualmente se pueden leer un total de 10 cartas completas escritas por ella, 1 carta de la cual Hipólita fue receptora, y 7 fragmentos de otras cartas que escribió. La gran mayoría de cartas conservadas se dirigen a su confesor, el Maestro fray Raimundo Sansón, y se escribieron en catalán, su lengua materna. Sin embargo, en su biografía, Antonio Lorea las traduce al castellano para que las lea el gran público. Esta probablemente no será la única modificación que introduzca su biógrafo, hay que tener en cuenta que existe la posibilidad de que manipulara las cartas al incluirlas en la obra con tal de demostrar ese carácter de santa de sor Hipólita. De varias cartas extrae únicamente fragmentos, dejando de lado el resto por no servir a sus propósitos e incluso en una de las cartas que, en teoría, se transcriben íntegras, Lorea admite haber dejado párrafos fuera deliberadamente: «Después de otras cosas, prosigue la Venerable Madre». ${ }^{36}$ Por lo tanto, aunque lo que leemos ha sido efectivamente producto de la

34. La única manera de que una de estas cartas no sufriera la obligada revisión era que se calificaran como «de conciencia». Estas eran las que se enviaban normalmente a los confesores, siendo así privadas pues las superioras no debían leerlas. El confesor podría contestar de la misma manera, evitando de nuevo la revisión.

35. LAiA DE Ahumada BAtlle: «La carta privada a l'època moderna: un epistolari conventual femení inèdit», en Manuscrits: Revista d'història moderna, n²9, 2011, pp. 51-64.

36. LOREA: La venerable madre [...], p. 96. 
mano y pluma de sor Hipólita, es necesario tener presente que puede haber sufrido modificaciones. ${ }^{37}$

A continuación, analizaremos los diferentes rasgos de la vida y personalidad de Hipólita extraídos de la lectura detallada de estas fuentes:

1. Autodevaluación. En las cartas se pueden leer numerosas expresiones de humildad exageradas, una manera insistente de infravalorar su persona, considerándose a sí misma una pecadora sin remedio. Es por ello por lo que desea una y otra vez infligirse numerosos tormentos como el ayuno, sacrificios que su confesor no le permite llevar a cabo puesto que su salud es muy débil. En consecuencia, ella expresa su sufrimiento ante la perspectiva de no poder llevar a cabo esos castigos «merecidos». Concretamente en una de las cartas, Hipólita insiste en ayunar por Cuaresma, obedeciendo lo que manda la santa Iglesia; pero su débil condición no se lo permite y tanto la priora como el médico le prohíben ayunar. Ella expresa su frustración pero, sobre todo, su preocupación por no poder cumplir con las penitencias necesarias para su alma. Esta carta fue escrita y dirigida tanto a su confesor, el maestro Sansón, como a otro padre, el maestro Fray Pedro Guasc, ${ }^{38}$ para suplicarles que ambos le permitieran ayunar: «el fin principal porque escribo esta juntamente a los dos, es por suplicarles humildemente y con muchas veras que pues los dos tienen oración larga y tratan de veras con Dios, que me alcancen su inmensa liberalidad, el grandísimo don del santo ayuno». ${ }^{39}$

Podemos observar numerosos ejemplos de expresiones de humildad en sus cartas:

- Hablando sobre sus escritos, no desea que se conozca su nombre, solo permanecer en el anonimato: «jamás he deseado ser conocida

37. Una aportación interesante de Antonio de Lorea es que explica que existían en aquel momento varias cartas de sor Hipólita que guardaba su sobrino y expresa su deseo de ver esas cartas editadas en un libro, a modo de otros personajes importantes cuyo epistolario habría sido publicado. Sin embargo, esto nunca llegó a suceder y las cartas, a día de hoy no sabemos si siguen existiendo: «Las cartas originales, escritas de la mano de esta Esposa de Cristo, las guarda con todos los demás escritos, el Excelentísimo Señor Don Fray Juan Tomás de Rocabertí, Arzobispo, y Virrey de Valencia, su sobrino. Bien quisiera yo, que todos gozaran de todas en libro aparte, con notas para la inteligencia de algunas cosas que la piden; $y$ atendiendo a orden superior, que me lo manda, he hecho elección de algunas, encerrándolas en el límite de este Capítulo». Visto en LOREA: La venerable madre [...], p.87.

38. Según Lorea el maestro fray Pedro Guasc era religioso de la Orden de Predicadores, «vivió en el Convento de Santa Catalina Mártir de Barcelona, con grande opinión de virtud y fundó en la mesma Ciudad el Convento de San Raymundo donde su cuerpo descansa, con opinión de Santo». Visto en LorEa: La venerable madre [...], p.89.

39. LOREA: La venerable madre [...], p.89. 
de ninguno, sino de Jesucristo, de su Santísima Madre y de los Santos del Reino de los Cielos».40

- Se considera a sí misma como gran pecadora: «Pero como me veo tan pecadora y tan indigna de que Dios me trate con tantos regalos espirituales $(. .). »{ }^{41}$

- «considerando yo ser la pecadora más culpada, y necesitada más que todos, fue mi espíritu inflamado en el amor de Dios $»^{42}$

- Se insulta y desprecia: «Suplico a V. Paternidad que pues tiene allá dos libros escritos y dictados de este vilísimo gusano despreciable, que no me obligue más a escribir por ahora y descansemos unos días». ${ }^{43}$

Cabe destacar que las comparaciones con otras religiosas de similares condiciones indican que, los autodesprecios suelen ser expresión acostumbrada, casi prescriptiva. Sin embargo, en muchos casos todo quedará en una breve despedida, que resalta la humildad de la escribiente (humilde servidora, indigna abadesa, menor súbdita etc.), expresión de carácter prácticamente obligatorio en la correspondencia de una religiosa. En el caso de Hipólita, no obstante, las cartas contienen una mayor expresión de autodesprecio, similar a las utilizadas por la religiosa sor Mariana de Jesús (1555-1635), contemporánea de Hipólita, franciscana descalza en Trujillo. ${ }^{44}$

2. Conocimiento de la doctrina. También se observa a través de sus cartas cómo Hipólita demuestra conocer el evangelio y las doctrinas de los Santos Padres de la Iglesia. Se pueden leer numerosas citas en latín extraídas de los Evangelios, de San Agustín, de David, de Jeremías, también de San Gerónimo, del profeta Daniel, los Salmos, las palabras de San Bernardo, de Santo Domingo, etc. Este hecho, que sorprende tanto a su biógrafo como a los censores que revisan la obra, transmite la idea de que realmente Hipólita es una persona instruida. Al contrario de lo que piensan los hombres que intentan entenderla, dando por hecho que su condición de mujer, y el haber entrado tan joven en el convento, harían de ella una persona con poca instrucción, poco conocimiento y, además, poca capacidad; la realidad es que es una mujer

40. Ibidem, p. 73.

41. Ibidem, p. 103.

42. Ibidem.

43. Ibidem, p. 113.

44. Las cartas de sor Mariana de Jesús han sido editadas en M. Ángeles de la CÁMAra Maneiro, Estudio sobre la Vida de sor Mariana de Jesús (Trabajo de Fin de Máster), Universidad Nacional de Educación a Distancia, Madrid, 2019. 
con bastantes recursos y demostrados conocimientos de religión, del evangelio y de las enseñanzas de los Santos Padres. ${ }^{45}$ Esa supuesta ignorancia suya hace que sus escritos se consideren de inspiración divina y adquieran por lo tanto más valor. En palabras de Poutrin:

Mujer y sin estudios de latinidad, era evidente que sor Hipólita había recibido, por un favor especial de Dios, las «superiores ilustraciones» y «celestiales luces» sin las cuales no hubiera podido escribir; entraba así en la categoría bastante selecta de las «mujeres místicas escritoras», cuya figura emblemática era santa Teresa de Jesús. ${ }^{46}$

A pesar de que Trento habría prohibido la libre interpretación de la Biblia y su lectura en lenguas vulgares, Hipólita dice haberla leído, ${ }^{47}$ y de ahí posiblemente su conocimiento de los santos profetas y sus citas. Se puede leer: «(...) por lo cual tuve dulcísimos coloquios con este contemplativo Profeta Daniel, por haber gustado muchas veces de sus Divinas Profecías leyéndolas, no solo en la Biblia, pero mucho más en la oración mental». ${ }^{48} \mathrm{Si}$ bien todo parece indicar que sor Hipólita habría tenido a su disposición los instrumentos necesarios para adquirir los conocimientos que exhibe (debido a su condición de religiosa), no se puede restar mérito a una persona que había conseguido comprender y trató de transmitir la compleja teología del momento.

3. Miedo a las represalias. Un aspecto importante que se puede extraer de sus cartas, es que sor Hipólita expresa aparentemente gran dependencia de su confesor, pues todo lo que hace lo consulta o comunica al maestro Sansón. De esta manera estaría asegurándose de no cometer errores en sus acciones o pensamientos, es decir, de no incurrir en herejía. Lo que hay detrás de esa dependencia es el miedo, el miedo a equivocarse ante el peligro de represalia. Sor Hipólita evidencia en la primera carta transcrita en su biografía, que todo lo que hace es por

45. Es más, según María Laura Giordano en su estudio de la figura de sor Hipólita, el convento donde vivía debía ser un lugar donde predominara el conocimiento de la liturgia y la teología: «el nivel de conocimiento y de familiaridad con las Escrituras en el monasterio dominicano de Nuestra Señora dels Àngels de Barcelona tuvo que haber sido de entre los más elevados de la época», un contexto que a buen seguro ayudó a desarrollar sus pensamientos y enseñanzas. Visto en MARía LAURA GIORDANO: «La «redención» del tiempo perdido. La dominica sor Hipólita de Jesús y la enseñanza de la Biblia en tiempos de la Contrarreforma», en Rosa MAría Alabrús (ed.): La vida cotidiana y la sociabilidad de los dominicos: entre el convento y las misiones (siglos XVI, XVII y XVIII), San Cugat, Arpegio, 2013, p. 155.

46. Isabelle Poutrin: «Censura y elogios. Los paratextos de las obras de sor Hipólita de Jesús (1679-1683)» en CRITICÓN, n 125, 2015, p. 113-114.

47. Se entiende que sor Hipólita habría leído la Vulgata, única versión admitida por el Concilio de Trento y de ahí también sus continuas citas en latín.

48. LOREA: La venerable madre [...], p.103. 
consejo de su confesor. En caso de que alguna de sus acciones fuera vista como sospechosa por la Inquisición, el contenido de esta carta sería prueba de exculpación, pues ella no hacía nada sin el permiso del maestro: ${ }^{49}$

Porque bien sabe v.P. que yo no tengo cosa de importancia, que no comunique, y en que deje de consultar a v.P. y siempre desde que Dios me hizo merced de que le conociese, y comunicase, siempre he seguido sus consejos, llenos de temor de Dios y de discreción: con que me ha ido muy bien, y confío morir debajo de su religiosa disciplina. ${ }^{50}$

Este recurso se podría considerar en cierta forma algo habitual. Como indicaba Doris Moreno, muchas mujeres aplicarían la que denomina «retórica de la feminidad», ${ }^{51}$ es decir, subrayar la debilidad de su propio sexo aprovechándose de la creencia mayoritaria en la debilidad de la mujer, su inferioridad intelectual y su infantilización, recurriendo así a la devaluación de sí mismas para quedar libres de culpa y sobrevivir, por ejemplo, a un proceso inquisitorial. ${ }^{52}$ Podría ser un buen ejemplo de esa expresión de falsa llaneza en la que la propia religiosa destaca su simpleza para protegerse de acusaciones, aprovechando la consideración de inferioridad que de ellas tienen sus superiores y en general la sociedad.

En este sentido, sor Hipólita comunica a su confesor también haber tenido visiones, como por ejemplo una visión de San Juan Bautista que le transmitía la necesidad de fundar un nuevo convento. Pero al mismo tiempo, expresa sus dudas sobre la autenticidad de esta, dudando si era realmente una santa revelación o, tal vez, obra del diablo, enviada para confundirla. Este apunte es fundamental. Si hubiese llegado a oídos de la Inquisición que sor Hipólita tenía visiones o arrobamientos, podrían haber puesto en cuestión su veracidad y represaliarla por ello. Así, ella misma incluye en su explicación la posibilidad de que esas visiones no sean tales, sino trampas del demonio. De esta manera se protege e intenta no incurrir en una falta grave:

49. Cabe destacar la existencia de casos como el de la terciaria Ana Domenge que, habiendo sido acusada ante la Inquisición por sus arrobamientos, dirigirá finalmente la culpa hacia su confesor, al cual se le abrirá un proceso. En este sentido, el responsable de sus faltas es aquel que la había guiado en su camino espiritual.

50. LOREA: La venerable madre [...], p. 72.

51. Término ya empleado por Alison Weber y analizado ampliamente en su detallado estudio sobre la obra de Santa Teresa. Alison Weber: Teresa of Avila and the Rhetoric of Femininity, New Jersey: Princeton University Press, 1996.

52. Doris Moreno: «Aproximación al nicodemismo del protestantismo español del siglo XVI. Lenguaje y prácticas sociales», en Studia Historica. Historia Moderna, vol. 40, n¹, 2018, p. 64 
Estando en los pensamientos de fundación de un nuevo Monasterio, un día de San Juan Bautista, luego que hube recibido el Santísimo Sacramento, sin pensar yo en este santo, me pareció, que este santo estaba presente en mi alma, y que delante de Iesu Christo, a quien tenía presente en el Sacramento, sin pensar yo en aquel punto en cosa alguna de fundación, me dijo: que hiciese la fundación, que él me ayudaría con su intercesión, para que yo pudiese ayunar. Y sabe Iesu Christo, que estaba presente, que yo digo verdad. Pero como el demonio es tan sutil: ¿qué sé yo si fue astucia, y engaño suyo, mereciéndolo mis pecados? ${ }^{53}$

Hipólita llega a declarar en otra $\operatorname{carta}^{54}$ que su espíritu fue elevado al Coro de los Santos Profetas y fue capaz de hablar con ellos, inundándose su espíritu de amor a Dios. De nuevo estamos ante una confesión peligrosa. Hipólita está hablando de favores que Dios le hace, que la elige de entre las demás para concederle estas visiones o arrobamientos. Por ello siempre muestra prudencia, y procura pedir a su confesor que sea él quien le aclare si son visiones de Dios o no, expresa: «lo que Dios obra en la oración mental en el lugar que v.P. sabe y allí lo verá, para poderlo examinar con mucho rigor si hay engaño o error, de lo cual siempre estoy con miedo». ${ }^{55}$

En esta época existía en la Iglesia del momento un verdadero escepticismo con respecto a estas manifestaciones divinas. Era frecuente que las visiones fueran muchas veces achacadas al demonio y varias de las mujeres que sufrieron esos arrobamientos fueron procesadas por la Inquisición por alumbradas o falsas visionarias. ${ }^{56}$

4. Humildad. La sexta carta ${ }^{57}$ que se transcribe en su biografía reviste especial interés. En esta respuesta de sor Hipólita a una carta previa de su confesor, podemos leer que la venerable madre había escrito un libro (no es el primero pues asegura que ya tiene otros escritos) por su mandato. ${ }^{58}$ Sin embargo, ella insiste en que no quiere que se conozca

53. LOREA: La venerable madre [...], p.90.

54. Ibidem, p. 96.

55. Ibidem, p. 104.

56. Resonaban ejemplos como los de Magdalena de la Cruz (1487-1560), Francisca de los Apóstoles (1541-final s. XVI), o María de la Visitación (1551-principios xviI) casos sonados y conocidos por la población, sus procesos constituían claras advertencias para el resto de las mujeres que desearan expresar manifestaciones similares.

57. LOREA: La venerable madre [...], pp. 109 a 115.

58. La escritura de obras por mandato del confesor fue habitual durante la Edad Moderna. Este mandato era fundamental para que las religiosas tuvieran el «permiso» de escribir, pero al mismo tiempo la obligación, suponiendo para muchas de ellas (según expresaban) una auténtica tortura, como en el caso de Ana de San Agustín (1555-1624), pues no deseaban escribir. El motivo por el cual no desearían escribir ya sería objeto de un análisis más profundo. Se puede leer sobre la carmelita y sus autobiografía 
su nombre: «Y esto es por confirmarme en mi intento, y propósito de que ni aun después de mi muerte quiero que en mis escritos se sepa mi nombre». Todo esto lo expresa después de explicar su temor a caer en el pecado de la soberbia y, por tanto, en línea con esa humildad que caracteriza todos sus escritos, pide que ni aun cuando muera, se conozca su nombre como autora de los libros.

Sin embargo, lo que es especialmente interesante de esta carta es que, al parecer, su confesor el Maestro Sansón le habría escrito previamente cuestionando la autoría de su obra. Esto transmite esa idea generalizada (incluso después de su muerte, por los encargados de valorar sus obras), de que siendo una mujer que además no había recibido instrucción elevada de teología y latín, era casi imposible que hubiese escrito esos textos caracterizados por un gran conocimiento de la teología, las escrituras y la ortodoxia cristiana (si no fuera por inspiración divina). $\mathrm{Su}$ propio confesor está dudando de sus capacidades. Ella se defiende en esta carta ante esa duda o acusación del maestro Sansón y reafirma su autoría diciendo: «¿En lo que v.P. me dice, si hay dos autores? No por cierto, sola yo miserable lo soy, así en el escribir como en el dictar; así de este libro como de los otros que tengo escritos». ${ }^{59}$

También apunta ella misma que ha escrito en castellano, a pesar de que su lengua materna es el catalán, con el que se comunica, porque es la lengua más adecuada para el gusto del pueblo: «Y la causa porque he escrito en Castellano es, porque si el buen Jesús ordena que salgan a luz en algún tiempo, hagan así más efecto: porque he oído muchas veces, que al pueblo agrada más la lengua Castellana, que la Catalana». ${ }^{60}$ Podemos entrever así una clara intención de llegar a ser publicada, disimulada tras sus continuas expresiones de humildad y la declaración de no querer ser reconocida. Sor Hipólita intenta transmitir un sentimiento de pecadora humilde y errada, pero en esencia se puede captar el propósito de querer llegar al público, de transmitir sus ideas. Por ello escribe directamente sus obras en castellano, y por eso insiste en que es solo ella la autora de sus obras. Existe una aparente expresión exagerada de humildad, que transmite una gran autodevaluación, pero al mismo tiempo, se intuye un trasfondo de seguridad en sus enseñanzas y cierto autorreconocimiento. Se puede apreciar un cierto afán divulgador. De nuevo podemos entrever esa «retórica de la

en: Vincent Parello: «Entre el velo y la pluma: el discurso de la vida de la carmelita descalza Ana de San Agustín (1555-1624)», en Cahiers d'Études des Cultures Ibériques et Latino-américaines, n³, Université Tolouse Jean-Jaurès-Université Paul-Valéry, Montpellier, 2017.

59. LOREA: La venerable madre [...], p. 110.

60. Ibidem. 
humildad» de la que hablaba Alison Weber ${ }^{61}$ en su análisis sobre los textos de Santa Teresa, donde se aprecia una expresión aparentemente humilde que contrasta con ese auténtico deseo de llegar a la gente con sus escritos.

5. Reconocimiento externo. En la misma misiva anterior, también se puede leer a Hipólita respondiendo a una solicitud de consejo sobre un problema de salud que su confesor padece. Ella le recomienda un remedio tanto físico como espiritual. En este caso, aparentemente los papeles se han intercambiado y es la religiosa la que aconseja al confesor. Se puede comprobar así un creciente reconocimiento en quienes conocen a sor Hipólita, de una autoridad suficiente como para aconsejar a un superior quien, en teoría, debía aconsejarla a ella.

Además, sor Hipólita solicita a su confesor, de quien tanta necesidad de consejo manifestaba en sus primeras misivas, que dejen pasar un tiempo sin escribirse. Las tornas habían cambiado y era el maestro Sansón quien encontraba consuelo en sus cartas y sus palabras. Sin embargo, ella se erige como la persona que marca los tiempos de esa relación y no desea escribir. Se aprecia, por tanto, una clara evolución en la relación entre confesada y confesor. Sor Hipólita ya ha escrito varios libros, ha puesto sus ideas sobre papel, ha reflexionado y quiere transmitir su aprendizaje. Su confesor, el maestro Sansón, se convierte en el receptor de sus consejos, quien encuentra consuelo en sus palabras, dejando entrever, sin quererlo, la cesión de cierta autoridad o reconocimiento espiritual. Este último punto, además, se puede corroborar con su siguiente carta. En esta se puede leer cómo las propias hermanas de su convento le pedían que les leyera las escrituras. Sus propias compañeras reconocen en ella cierta autoridad en el conocimiento de la doctrina y la religión, y desean escuchar lo que tiene que decir. ${ }^{62}$ Ella, continuando con su acostumbrada humildad, se ve obligada a escribir a su confesor para pedirle permiso. Como hemos señalado, Sor Hipólita no actuaba sin comunicarlo todo primero a su confesor y solicitar su aprobación:

Lo que ahora se me ofrece de nuevo es, que algunas Religiosas, mozas y ancianas, así legas como del Coro, me han rogado, que los días de fiesta,

61. Alison Weber: Teresa of Avila and the Rhetoric of Femininity, New Jersey: Princeton University Press, 1996.

62. No solamente sus hermanas reconocen en ella cierta autoridad, también era reconocida por los vecinos, fuera del convento, por ejemplo, entre las viudas: «las viudas acreditan una vez más su fama de maestra espiritual fuera de las paredes del monasterio, ya que pedían su consejo y ella las animaba a entregarse a la palabra de Dios y a la oración». Visto en: GIORDANO: «La redención del [...]», p. 157. 
y Domingos, les declare la letra de la Epístola, y Evangelio de aquel día, y en fin el día de San Lucas y en este último. [...] Con todo ello, vea v.P. si le parece: porque pues me rijo por v.P. sino le parece, sin duda no lo haré. En esta mesma mañana, me ha rogado una Religiosa del Coro, de las ancianas, con grande insistencia que le declarase la Epístola y el Evangelio de esta santa octava. ${ }^{63}$

6. Crítica con cautelosa prudencia. Por último, la última carta transcrita en la biografía de Lorea no es dedicada a su confesor, sino a cierto prelado del que no especifica nombre. En ella, sor Hipólita se atreve a recordarle sus deberes como ministro de la Iglesia y le anima a caminar por el buen camino de la ortodoxia católica, es decir, le exhorta a la perfección. Para ello, se sirve de las enseñanzas de los Santos Padres y profetas de la Biblia, por lo que la carta está plagada de citas con las que habla del amor de Dios. Durante varios párrafos, y tras haber expuesto las enseñanzas de los buenos pastores y profetas como David, sor Hipólita se dedica a criticar a los «malos pastores». Habla de la falta de humildad y de sacrificio, pues no se sacrifican por «sus ovejas» porque son prelados únicamente por las tentadoras riquezas. Aquí se observa una de las críticas más frecuentes de la sociedad a los representantes eclesiásticos en el siglo xvi: la relajación de sus ministros. Sor Hipólita, eso sí, es consciente de que camina por una delgada línea, por lo que tiene el cuidado de no usar palabras mayores ni realizar ninguna acusación directa que pudiera haber levantado sospechas de «herejía reformadora». Ella se limitaría a hacer una sencilla advertencia esgrimiendo siempre las sagradas escrituras como razonamiento y la glorificación de Dios como único propósito de sus palabras:

No digo más, sino que ruego per viscera Christi, que el Señor, y Padre Obispo, que de veras desea dar su descargo en oficio pastoral, y dar buena cuenta al Omnipotente Dios justo Juez, y alcanzar la corona de justicia, como dice S. Pablo, como habemos dicho: procura tener oración mental cada día, y que una vez en el mes se haga leer este cap. 34 del Profeta Ezequiel: porque casi en todo él habla Dios con los pastores de su Iglesia, que como el sagrado, y divino Texto tiene tanta fuerza, y eficacia, al fin es viva palabra de Dios: no dudo yo que sus almas sacarán gran provecho, y sus ovejas también, y será Dios glorificado, que es lo que pretendemos solamente. ${ }^{64}$

63. LOREA: La venerable madre [...], p.119.

64. Ibidem, pág.162. 
Ese miedo o precaución que se intuye ante la posibilidad de ser acusada se puede identificar también en otro hecho: la carta no va dirigida directamente al prelado en cuestión, sino que la dirige a su confesor, el maestro Sansón, para que él la lea primero. Manifestando su humilde ignorancia, Hipólita no está segura de que la adecuación de lo escrito y solicita que, de no serlo, la carta sea destruida. ${ }^{65}$ De esta manera no quedarían pruebas de una posible muestra de soberbia, al haberse atrevido a reprender la actitud de un superior, que bien fácilmente podría sentirse ofendido (con graves consecuencias para ella).

En un apunte, el propio Lorea aclara: «Según se parece de las ultimas cláusulas de esta carta, lo escribió para algún señor Prelado, a quien fue necesario volverle a hacer recuerdo de las obligaciones en que estaba de su reformación: de amar a Dios, y servirle, y de amar y cuidar de sus ovejas». ${ }^{66} \mathrm{La}$ intención de sor Hipólita queda clara para Lorea, al igual que el hecho de proceder con mucha cautela, sin mencionar el nombre del prelado al que se dirige, sin firmar la carta y sin decirle al portador de la misma su contenido. En todo ello se aprecia la delicadeza de los tiempos y la necesidad de proceder con mucha prudencia para no ser acusada ante la Inquisición: ${ }^{67}$ "Con toda esta prudencia procede, para haber de advertir su obligación a un Prelado: porque no se vuelva en injuria, lo que es consejos, y él no se pase de avisado a ofendido».

7. Capacidad de gestión. En las últimas cartas encontradas en el Archivo de los Ángeles y publicadas por Laia de Ahumada ${ }^{68}$ se leen sobre todo asuntos referentes al gobierno del convento, ya sea como subpriora o como una de las enviadas al convento de las Magdalenas para reformarlo. También se observa algún asunto más mundano como es el de procu-

65. «Y así quemando v.P. esta carta, por muy buen fin que aya sido el que me ha regido: yo no tendría de dar cuenta de esta buena obra: y por ser yo tan ignorante, no puedo decir que esté buena: y asi con animo contrito, y el espíritu de humildad, lo dexo todo en manos de v.P. (y mi anima también) dilectísimo Padre, en Christo Iesús». LOREA: La venerable madre [...], p.163.

66. Ibidem.

67. Los tribunales inquisitoriales se encargarán así de llevar a cabo el proceso de «re-educación» de la Contrarreforma a través de la persuasión, pero sobre todo, a través de la represión. En palabras de Arturo Morgado, que escribe según lo visto en Prosperi (1999), el nuevo papel de la Inquisición durante la llamada Contrarreforma se podría explicar de la siguiente manera: «La educación de la colectividad por medio de rituales públicos como el auto de fe y la abjuración (con todo lo que ello implica de sometimiento al poder), la educación de la moralidad individual con el uso de medios coercitivos, introduciéndose la Inquisición en terrenos nuevos (la bigamia, la falsa o fingida santidad) que hasta entonces pertenecían al ámbito de lo privado, y, finalmente, la voz de la conciencia, a la cual la Inquisición supo dictar lo que había que decir, utilizando como aliado al confesor». Visto en: Arturo Morgado García: El clero en la España de los siglos XVI y XVII. Estado de la cuestión y últimas tendencias, Depósito digital UAB, 2007, pág. 93.

68. Ahumada Batlle: «La carta privada [...]», pp. 51-64. 
rar la herencia de los bienes de la señora Corregona ${ }^{69}$ para su convento de los Ángeles. De todo ello se recoge que sor Hipólita se preocupaba por estar bien informada y por contribuir al beneficio de su comunidad. Se puede apreciar cierta autosuficiencia en su proceder, ya que podía ocuparse de los asuntos de organización del convento y hacerlo de manera eficiente a través de sus conocimientos y contactos.

\section{Conclusiones}

Hipólita tiende a recurrir al disimulo de sus capacidades, a la prudencia a la hora de expresarse y a una humildad exacerbada, no solo en sus cartas sino en su vida y proceder. Se observa en ella también a una aparente dependencia de su confesor, que esconde el miedo a ser acusada de herejía, disfrazando una innegable autosuficiencia y seguridad en sus ideas y ortodoxia. En palabras de la historiadora Alabrús, ${ }^{70}$ sor Hipólita «recurre a la retórica de la falsa llaneza ya esgrimida con anterioridad por Teresa de Jesús. En el caso de Hipólita se convirtió en el principio de su discurso religioso, una especie de autonegación de sus capacidades, expresada desde el rechazo al cargo de priora a la valoración de su propia obra».

Hipólita fue además una mujer que, contrariamente a lo que se pensaba, habría estudiado las sagradas escrituras, las conocía y las citaba. Ya fuera por instrucción, ya por inteligencia o autoaprendizaje, Hipólita había llegado a conocer y comprender la compleja teología del momento, siendo profundamente ortodoxa en su proceder.

En conclusión, sor Hipólita fue un producto de la disciplina religiosa impuesta durante los tiempos de la Contrarreforma, tras la aplicación de las decisiones tomadas en el Concilio de Trento. Es el resultado de una época en la que religión y religiosidad fueron exaltadas desde las instituciones hasta tal punto que, personas como ella respondieron al adoctrinamiento con una rigidez espiritual férrea. Durante su vida insistió en asegurar su ortodoxia como resultado del miedo permanente a la herejía y a sus consecuencias, recurriendo al disimulo, a la autodevaluación, al anonimato y al silencio. Sin embargo, gracias a las cartas que hoy quedan podemos ver que, en realidad, era alguien con una gran personalidad, amplios conocimientos y la suficiente seguridad en sí misma como para atreverse a reprender a un prelado, a predicar entre sus hermanas o a escribir obras para el aprendizaje de toda la sociedad.

69. Àngela Jerònima Poch Codina, conocida como Corregona por su segundo marido, Galcerán de Corregó. Esta mujer al parecer cuidó a Hipólita y la crio como si fuera su propia madre. Visto en: Ahumada Batlle: «Hipólita de Jesús [...]», p. 139.

70. Alabrús Iglesias: «Los confesores [...], p. 102. 


\section{BiBLIOGRAFÍA}

Ahumada BATLle, LAIA DE: «La carta privada a l'època moderna: un epistolari conventual femení inèdit», en Manuscrits: Revista d'història moderna, nº29, 2011.

—: «Hipólita de Jesús. Biografía y bibliografía», en Rosa María Alabrús (ed.): La vida cotidiana y la sociabilidad de los dominicos: entre el convento y las misiones (siglos XVI, XVII y XVIII), Arpegio, San Cugat, 2013.

Alabrús Iglesias, Rosa María: «La espiritualidad de Hipólita de Rocabertí y la construcción de su imagen en el siglo xviı», en Hispania Sacra, vol. $67, \mathrm{n}^{\circ} 135,2015$.

-: «Los confesores y los relatos autobiográficos de monjas en la transición del siglo Xvi al siglo Xviı: Hipólita de Rocabertí y Ana Domenge», en Pedralbes: Revista d'història moderna, $\mathrm{n}^{\circ}$ 37, 2017, pp.95-114.

-: Razones y emociones femeninas. Hipólita de Rocabertí y las monjas catalanas del Barroco, Cátedra, Madrid, 2019.

Atienza López, Ángela: «Las grietas de la clausura tridentina. Polémicas y limitaciones de las políticas de encerramiento de las monjas...Todavía con Felipe IV», en Hispania, vol. LXxIV, nº 248, 2014, pp. 807-834.

-: «De reacciones, de tolerancias, de resistencias y de polémicas. Las «grietas» de la Contrarreforma y los límites del disciplinamiento social», en Hispania, vol. 74, n²48, 2014, pp. 651-660.

-: «Los límites de la obediencia en el mundo conventual femenino de Edad Moderna: polémicas de clausura en la corona de Aragón, siglo XVII», en Studia Historica. Historia Moderna, vol. 40, n 1, 2018, pp. 125-157.

-: «El mundo de las monjas y de los claustros femeninos en la Edad Moderna. Perspectivas recientes y algunos retos», en Eliseo Serrano Martín (coord.): De la tierra al cielo. Líneas recientes de investigación en Historia Moderna, vol. 1, Institución «Fernando el Católico», Zaragoza, 2012, pp. 89-108.

Baranda Leturio, Nieves y Marín Pina, M. ${ }^{a}$ Carmen: «El universo de la escritura conventual femenina: deslindes y perspectivas», en Letras en la celda: cultura escrita de los conventos femeninos en la España moderna, Tiempo emulado, Historia de América y España, 32, 2014.

Cámara Maneiro, M. a Ángeles de la: Estudio sobre la Vida de sor Mariana de Jesús (Trabajo de Fin de Máster), Universidad Nacional de Educación a Distancia, Madrid, 2019.

Fernández Terricabras, Ignasi: «Éxitos y fracasos de la Reforma católica. Francia y España (siglos XVI-XVII)», en Manuscrits: revista d'història moderna, núm. 25: Confessionalització i disciplinament social a l'Europa catòlica (segles XVI-XVIII), 2007, pp. 129-156. 
García CÁRCEL, Ricardo: «De la Reforma protestante a la Reforma católica: reflexiones sobre una transición», en Manuscrits: Revista d'història moderna, $\mathrm{n}^{\circ} 16,1998$, pp. 39-64.

Giordano, María Laura: "La "redención" del tiempo perdido. La dominica sor Hipólita de Jesús y la enseñanza de la Biblia en tiempos de la Contrarreforma», en Rosa MARÍA Alabrús (ed.): La vida cotidiana y la sociabilidad de los dominicos: entre el convento y las misiones (siglos XVI, XVII y XVIII), Arpegio, San Cugat, 2013, pp. 149-166.

Gómez Castillo, Antonio y Sierra Blas, Verónica (dirs.): Cinco siglos de cartas: historia y prácticas epistolares en las épocas moderna y contemporánea, Universidad de Huelva, Huelva, 2014.

Herrero Herrero, Maria Àngels: «Per manament del confessor: l'esclat de l'autobiografia femenina en l'Edat Moderna. El cas del Dietari espiritual de la il.licitana sor Gertrudis de la Santíssima Trinitat», en Ítaca. Revista de Filología nº1, Universidad de Alicante, Alicante, 2010, pp. 179-190.

Lorea, Antonio DE: La venerable madre Hipólita de Jesús y Rocabertí, religiosa de la orden de n.p.s. Domingo en el monasterio de nuestra Señora de los Ángeles de la ciudad de Barcelona. Epitome de su prodigiosa vida, virtudes y admirables escritos, sacados de los procesos de su beatificación, y canonización, y otros instrumentos auténticos, Vicente Cabrera, Valencia, 1679.

Moreno, Doris: «Aproximación al nicodemismo del protestantismo español del siglo xvi. Lenguaje y prácticas sociales», en Studia Historica. Historia Moderna, vol. 40, $\mathrm{n}^{\circ} 1,2018$, pp.31-73.

Morgado García, Arturo: El clero en la España de los siglos XVI y XVII. Estado de la cuestión y últimas tendencias, Depósito digital UAB, 2007.

Parello, Vincent: «Entre el velo y la pluma: el discurso de la vida de la carmelita descalza Ana de San Agustín (1555-1624)», en Cahiers d'Études des Cultures Ibériques et Latino-américaines, $\mathrm{n}^{\circ} 3$, Université Tolouse Jean-Jaurès-Université Paul-Valéry, Montpellier, 2017.

Pazzis Pi Corrales, Magdalena De: «Existencia de una monja: vivir el convento, sentir la Reforma (siglos XVI-XVII)», en Tiempos Modernos: Revista Electrónica de Historia Moderna, vol. 7, n² 20, 2010.

Poutrin, Is Abelle: Le Voile et la plume: autobiographie et sainteté féminine dans l'Espagne moderne, Madrid: Casa de Velázquez, 1995.

-: «Censura y elogios. Los paratextos de las obras de sor Hipólita de Jesús (1679-1683)» en CRITICÓN, no 125, 2015, pp. 107-119.

-: «Autobiografías», en Nieves Baranda Leturio y Anne J. Cruz (ed.): Las escritoras españolas de la Edad Moderna. Historia y guía para la investigación. UNED, 2018.

Ravina, Aurora: «Archivos revisitados: la correspondencia epistolar como fuente para la historia social», en Memoria Académica, La Falda, Córdoba, 2009. 
VAlerio, Adriana: «La Biblia, las mujeres y la crisis de la Europa Moderna» en M. L. Giordano y A. VAlerio (eds.): Reformas y Contrarreformas de la Europa Católica (siglos XV-XVII) ed. Verbo Divino, Navarra, 2016, pp. 11-38.

Van Dülmen, Richard: El descubrimiento del individuo 1500-1800, Siglo XXI España, Madrid, 2016.

Weber, Alison: Teresa of Avila and the Rhetoric of Femininity, New Jersey: Princeton University Press, 1996.

\section{FuENTES ORIGINALES}

CONCILIO DE TREnTo. Sesión xxv. 3 y 4 de diciembre de 1536. Los religiosos y las monjas.

Amb els suport de la Secretaria d'Universitats $i$ Recerca de la Generalitat de Catalunya $i$ del Fons Social Europeu. 